\title{
Throughput time reduction of limited test at a silk testing unit
}

\author{
D. Sargunamani ${ }^{1 *}$, K. Raghu ${ }^{1}$, Subhas V. Naik ${ }^{2}$ \\ ${ }^{I}$ Regional Silk Technological Research Station, Central Silk Technological Research Institute, Central Silk Board, Kancheepuram-631501, INDIA \\ ${ }^{2}$ Central Silk Technological Research Institute, Central Silk Board, Bengaluru-560068, INDIA \\ *Corresponding Author: e-mail: sargunamani@gmail.com, Tel: +(91) 044-27277583 \\ ORCID iD: http:/orcid.org/0000-0002-2652-2945 (Sargunamani), https://orcid.org/0000-0002- 8658- 8663 (Raghu), \\ https://orcid.org/0000-0003-2915-2588 (Naik)
}

\begin{abstract}
The present economic situation across the globe calls for intense efforts to maximize production in minimum throughput time and cost to enhance operating performance and the quality of products. The problem with manufacturing/ testing goods forces the process owners to be organised and direct attention to minimise the global throughput time within the manufacturing enterprise. Minimising time has a chain effect to enhance the worth of manufacturing/testing processes. The minimisation of cycle time consequently enhances the quality. This report describes an improvement process based on lean thinking in order to reduce throughput time of limited test (Denier test) for grading silk quality. For an implementation of the adaptive work, it is important to know about the time needed for the various steps involved adding their time to find the total time in the existing system by process mapping to find opportunities to reduce time. The results of the study show that time can be reduced in the process of limited test from $350 \mathrm{~min}$ to $220 \mathrm{~min}$ (Multiendsilk) and from 246 to $133 \mathrm{~min}$. (cottage basin)eliminating various causes such as waiting time, absenteeism so on thus improving throughput time. The novelty of the study is that it is the first one to apply total quality management concept in silk testing unit for throughput time reduction from which a standard table has been created for limited test (avoiding non value added activities) for referring for throughput time involved to complete silk denier test faster.
\end{abstract}

Keywords: Multiend silk, Cottage basin silk, throughput time, Kilcha, Denier

DOI: http://dx.doi.org/10.4314/ijest.v12i3.4

Cite this article as:

Sargunamani D., Raghu K., Naik S.V. 2020. Throughput time reduction of limited test at a silk testing unit. International Journal of Engineering, Science and Technology, Vol. 12, No. 3, pp. 26-37. doi: 10.4314/ijest.v12i3.4

Received: November 14, 2019; Accepted: July 9, 2020; Final acceptance in revised form: July 25, 2020

\section{Introduction}

Reducing throughput time is an important factor in an industrial project. Throughput time is the total elapsed time from the start of the process flow of the service to delivery (Holweg et al., 2018, https://mn.gov/admin). Reductions in manufacturing throughput time can generate numerous benefits, including lower work-in-process and finished goods inventory levels, improved quality, lower costs, and less forecasting error. More importantly, increased flexibility and reduced time required to respond to customer orders are the focus of throughput reduction. This can be vital to the survival and profitability of numerous firms, especially those experiencing increased market pressures for shorter delivery lead times of the customized product (Johnson, 2003; Johnson and Wemmerlov, 1998). Another study (Allahverdi and Soroush, 2008) defined set-up time as obtaining tools, positioning, work in process material, returning tools, cleaning up, setting the required jigs and fixtures, adjusting tools and inspecting materials in the manufacturing process. Yadav et al. (2012) used a VSM technique by mapping the whole process and proposes layout changes to 
reduce transportation time. Method study concept like parallel activities and combined concept are being applied to reduce processing time. Other previous research on throughput time factors on processing time per part (Suresh and Meredith, 1994), process variability (Athersmith and Crookall, 1974) and resource utilization and/or resource availability (Ang and Willey, 1984; Garza and Smunt, 1991) has been reported by various authors.

Plossl (1988) studied and presented the beneficial effects of better control (meaning reduction) of throughput times in all phases of planning, execution and control of manufacturing and showed how well-run companies are achieving such reductions. Van der Heijden et al. (2013) developed a heuristic for the joint optimization of spare part inventories and TPTs in repair and supply based on pricing of TPT reductions for multi-item, multi-echelon, multi-indenture spare part networks. Their heuristic is easy to apply and yields significant cost reductions compared to the standard VARI-METRIC method for spare part optimization where TPTs are fixed. They found that it is particularly profitable to reduce TPTs downstream in the supply chain. Repair TPT reduction of lower indenture items upstream in the supply chain is least useful.

Johnson (2003) has studied the basic factors that determine MTTP and explained why each factor impact occurs to educate workers on basic concepts. They also did conceptual framework that illustrated the actions that can be taken to reduce each factor (reduced set up time, scrap, move, operations, no. of operations, batch size, resource utilization etc.) and the relationship between them, which becomes easy tool for managers to reduce MTTP in their own plants. Blocheret al. (2009) studied managing throughput time and its relation to work $\square$ in $\square$ process inventory and customer service. This research combined theory, simulation results, and the analysis of corporate data in an effort to address the issues associated with how one company (Eli Lilly) managed a reduction in their throughput times and an improvement in their delivery reliability. The results for this company suggest that production control decisions - expediting and de $\square$ expediting — can lead to a vicious circle of decisions, which in turn can lead to increased levels of WIP inventory and higher and more unpredictable throughput times. Eberle et al. (2014) asserted that reliable product supply is one of the most critical missions of the pharmaceutical industry. The lead time, i.e. the duration between start and end of an activity, needs to be well managed in any production facility in order to make scheduling predictable, agile and flexible. They presented a method for measuring and improving production lead time of pharmaceutical processes with a primary focus on Parenterals (i.e. injectables) production processes.

Based on the above, it is thought that, Time reduction studies are also, always essential in various processes of government organizations. Therefore, this study aims to implement throughput time reduction at Regional Silk Technological Research Station (RSTRS) [Previously Silk Conditioning and Testing House-SCTH], CSTRI, Central Silk Board, Kancheepuram for limited test (Denier test) to grade raw silk for auction purpose and price fixation for the customer Anna Silk Exchange, Kancheepuram, which is under Directorate of Sericulture, Salem. The study reports the identification of non-value added activities by process mapping of limited test of two types of silk a) Multiend and b) Cottage basin to cut down the time thereby reducing throughput time for faster delivery of reports for satisfying the customer.

\section{Materials and Methods}

Raw silk testing of multiend and cottage basin reeling skeins is received from Anna Silk Exchange of denier range 18-22 used for testing purposes on various days in a week. Winding test is carried out using winding machine at a predetermined speed of 140 $\mathrm{m} / \mathrm{min}$. For a denier range of 13-18 to 19-33 of preliminary winding of $10 \mathrm{~min}$. and then a normal winding period of $60 \mathrm{~min}$. of total $70 \mathrm{~min}$. is carried out. The number of breaks that occur are counted and noted. When breaks occur, it is necessary to note the cause of each break and this should be recorded. Wrap reel machine to wind silk skeins of 1:125 $\mathrm{m}$ in circumference is used to produce lengths of cottage basin about $225 \mathrm{~m}$ and multiend $450 \mathrm{~m}$. Kilcha (slight twist) for wound silk is done manually using Kilcha winder. Denier test (Size) and size deviation test is carried out using inbuilt software. Twenty samples in each lot are weighed on a scale for finding out test results. Stop watch was used for the time study of the limited test process to improve the existing process (Figure 1). The method adopted is practical, achieved by a visiting process, talking with people, knowing the current situation in, and then analyzing time data and try to find out where the problem occurs then get solution to work out the method for improvement.

\section{Analysis}

Figure 2 shows the Total Time taken for process completion of limited test for multiend silk samples of throughput time from collection of silk samples to submission of test reports. It can be observed from the figure that first three months (from June 17 to August 17), data were collected for the study observation. The average total time was varying between $250 \mathrm{~min}$. to $350 \mathrm{~min}$. The causes have been identified for an existing throughput time that can be reduced are: personal work of workers after collection of silk samples and before loading waiting time (30\%), Waiting time of operator to start the machine for various reasons (20\%), Improper allotment of required workers per machine (15\%), Computer, printer and denier software related problems and allotment of Staff for denier test (15\%), Worker Absent (5\%), Some faulty parts causing idle time in machines (5\%), The improvement required in loading of silk samples and Supply of bobbins in right time, which is a day before preparation for next day schedule $(5 \%)$ and lack of motivation (5\%). 


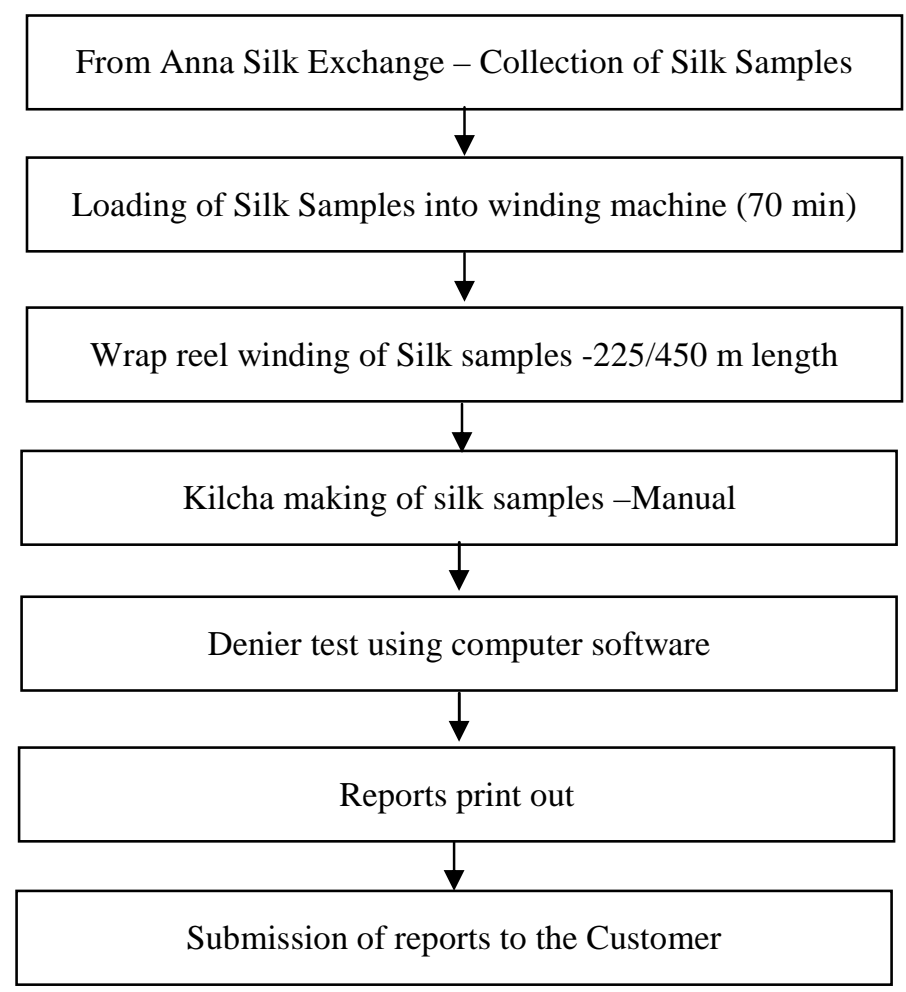

Figure 1. Process mapping of Limited test (Denier test) of silk samples

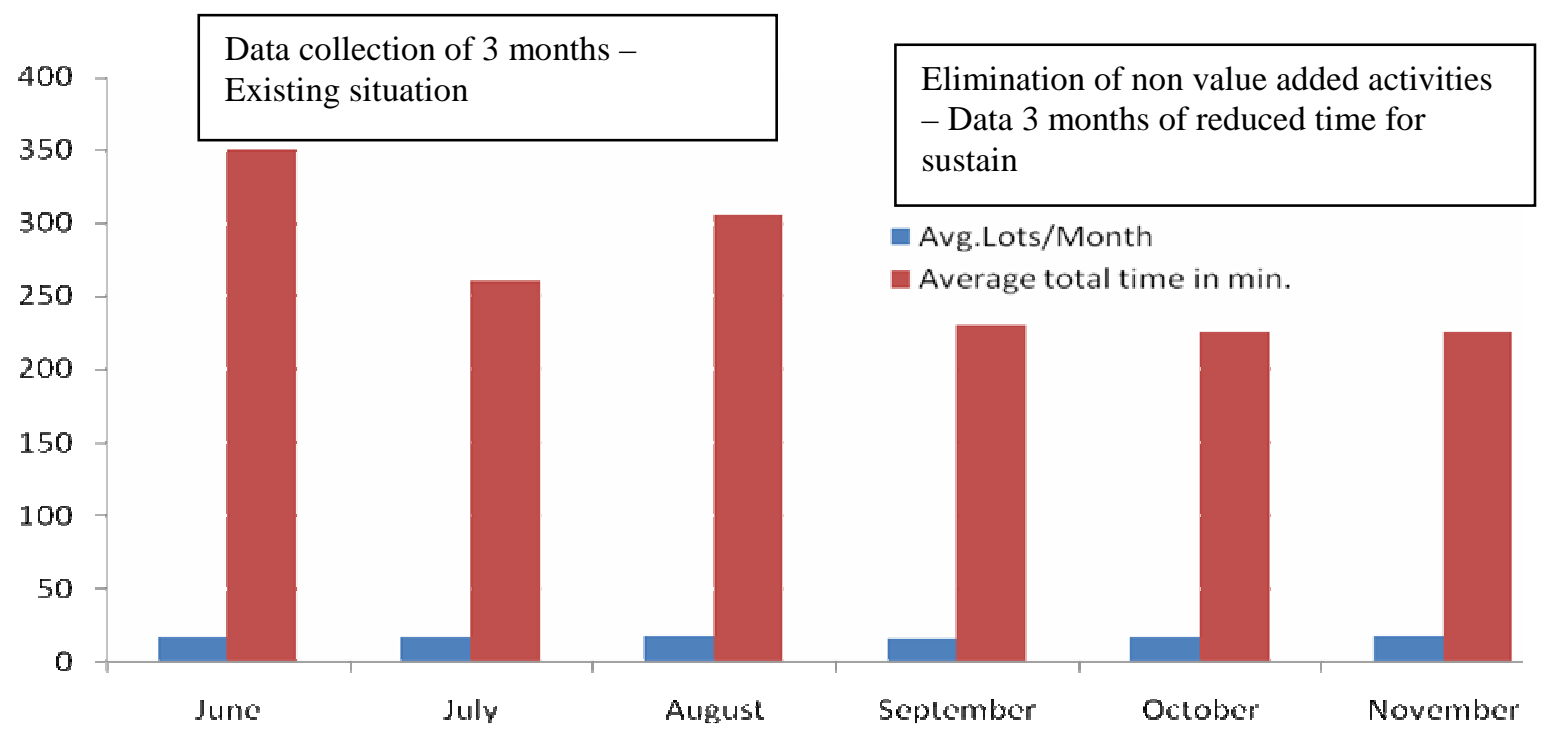

Figure 2. Average Total Time month wise year 2017 for Limited Test for Multiend silk samples of average 18 lots with 5 workers

The above causes have to be reduced to get a reduction of throughput time. Therefore, the above problems as far as possible have been solved by following instructing to workers to avoid personal work, waiting time and absenteeism of various reasons (Johnson, 2003). Computers and printers are updated for smooth working. Some machines are adjusted for the proper working and minor improvements made in motor pulley, belt, thread guide and oiling for the machine. Loading of silk samples done based on the Parallel method (Andersen, 1999) of changing the current method of allotment of worker/staff from 4 to 2 per winding machine and from 5 to 3 in 3 wrap reel machine and for Denier test using computer 2 staff were put to work in parallel instead of one for effective manpower utilization (Jelena et al., 2014; Ang and Willey (1984). The method of loading of silk samples has been improved and preparation for the next day schedules, streamlined by proper planning. With these changes, it can be seen from the Figure 2, from September 17 to November 17 in 3 months duration, throughput time has reduced significantly. For an average of 18 Nos. of samples throughput time has reduced from $350 \mathrm{~min}$ to $220 \mathrm{~min}$. thereby achieving the target. 
From Figure 3, it can be observed that after implementing the above solutions for the Cottage basin silk testing as discussed above, the throughput time is reduced from $246 \mathrm{~min}$ to $133 \mathrm{~min}$. The manpower utilization modified for proper utilization by changing from 5 to 2 Nos. workers to produce average 10 samples per winding machine and the remaining 3 Nos. workers have been allotted other work. The production and quality of silk samples remained same even after reducing manpower, thereby achieving the target of throughput time reduction. Throughput time reduction was observed by Naik et al. (2011) in which the study clearly indicated that by eliminating non value added activities in cutting section time as well as cost is saved besides improving internal throughput time.

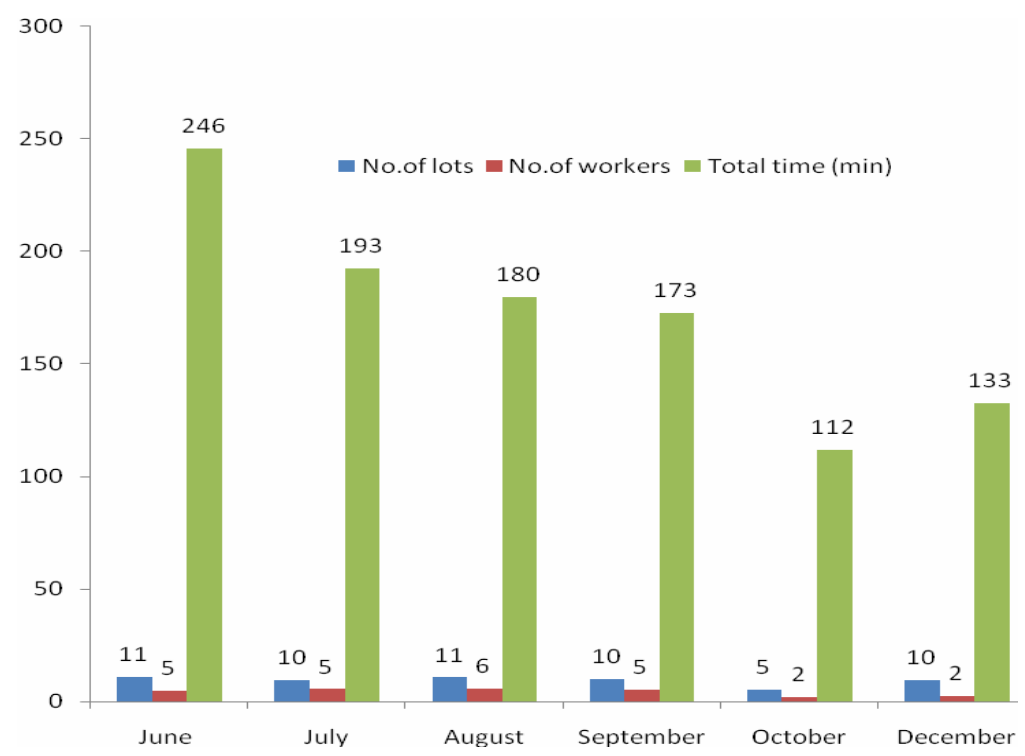

Figure 3. Average Total Time month wise year 2017 for limited test for Cottage basin silk samples

Further, the critical step in the process of denier test is found to be Kilcha making-manually which is the fourth step from the top in Figure 1. This work consumes higher time and manpower causing delay of the process. Therefore a new machine is designed named "Automatic skeining (Kilcha) machine" which reduces time further by $40 \%$ of total time of limited test used in the process resulting in throughput time reduction. First time, in silk testing unit, based on the study, a standard table (Table 1) has been created as ready reference for limited test to inform the customers to refer for throughput time involved for faster delivery of test results than previous which is the novelty.

Table 1. Reference table for throughput time for limited test of multiend silk

\begin{tabular}{|c|c|c|c|c|c|c|}
\hline Sl.No & No. of lots & $\begin{array}{c}\text { No. of } \\
\text { Workers }\end{array}$ & $\begin{array}{c}\text { No. of winding } \\
\text { machines }\end{array}$ & No. of wrap reel & $\begin{array}{c}\text { No. of computers } \\
\text { for denier test }\end{array}$ & $\begin{array}{c}\text { Estimated throughput } \\
\text { time (in min.) }\end{array}$ \\
\hline 1 & $1-5$ & 2 & 1 & 1 & 1 & 120 \\
\hline 2 & $5-10$ & 2 & 1 & 1 & 1 & 160 \\
\hline 3 & $11-15$ & 4 & 2 & 2 & 2 & 200 \\
\hline 4 & $15-20$ & 4 & 2 & 2 & 2 & 230 \\
\hline 5 & $26-30$ & $4-5$ & 2 & 2 & 3 & 260 \\
\hline 6 & $26-30$ & $4-5$ & 2 & 3 & 3 & 200 \\
\hline 7 & $21-25$ & 6 & 3 & $3-4$ & 3 & 240 \\
\hline 8 & $26-30$ & 6 & 3 & $3-4$ & 3 & \\
\hline
\end{tabular}




\section{Conclusion}

The study reveals that by process mapping of limited test (Denier test) performed for silk samples throughput time can be reduced by eliminating non-value added activities. Throughput time reduced from 350 minutes to 220 min for multiend silk and $246 \mathrm{~min}$ to $133 \mathrm{~min}$. for cottage basin silk for limited test. The submission of test results reports delivery time is reduced, thus satisfying customer, which are the advantages along with proper maintenance of machines, reduced absenteeism, effective utilization of man power. Further, a standard table has been created as ready reference for limited test to inform the customers to refer for throughput time involved. There is scope for implementing these total quality management concepts in silk - all test, zari testing and in other physical and chemical testing methods.

\section{References}

Allahverdi A., Soroush H.M. 2008. The significance of reducing setup times/setup costs. European Journal of Operational Research. Vol. 187, No. 3, pp. 978-984. https://doi.org/10.1016/j.ejor.2006.09.010

Ang C.L., Willey P.C.T., 1984. A comparative study of the performance of pure and hybrid group technology manufacturing systems using computer simulation techniques. International Journal of Production Research, Vol. 22, No. 2, pp. $193-233$.

Andersen B., 1999, Process cycle time reduction, A back-to-basics look at removing bottlenecks, Quality Progress (http://asq.org/quality-progress/1999/07/one-good-idea/process-cycle-time-reduction.html).dtd source accessed on 31.07.2018.

Athersmith D., Crookall J. R., 1974. Some organizational aspects of cellular manufacture based on computer simulation, Proceedings of the 15th Machine Tool Design and Research Conference, Sept. 18-20, Birmingham, UK.

Blocher J.D., Garrett R., Schmenner R.W. 2009, Throughput time reduction: Taking one's medicine, Production and Operations Management, Vol. 8, No. 4. (https://doi.org/10.1111/j.1937-5956.1999.tb00313.x)

Eberle L.G., Sugiyama H., Schmid R.S. 2014, Improving lead time of pharmaceutical production processes using Monte Carlo simulation, Computers \& Chemical Engineering, Vol. 68, pp. 255-263.

Garza O., Smunt T. L., 1991, Countering the negative impact of intercell flow in cellular manufacturing, Journal of Operations Management, Vol. 10, No.1, pp. 92-118.

Holweg M., Davies J., De Meyer A.., Schmenner R. 2018. Process Theory: The Principles of Operations Management, Published in USA by Oxford University Press, New York, p.75.

https://mn.gov/admin/assets/measurement_glossary_handout_tcm36-68778.pdfdtd source accessed on 31.07.2018.

Jelena R. J., Dragon D., Milanovic., Radisav D., Djukic. 2014, Manufacturing cycle time analysis and scheduling to optimize its duration, Journal of Mechanical Engineering, Vol. 60, No. 7-8, pp. 512-524.

Johnson D.J. 2003. A framework for reducing manufacturing throughput time, Journal of Manufacturing Systems, Vol. 22, No.4, pp. 283-298.

Johnson D. J., Wemmerlov U., 1998, Cellular manufacturing feasibility at Ingersoll cutting tool Co. Chapter E2 in Group Technology/Cellular Manufacturing, A State of theArt Synthesis of Research and Practice, Suresh N.C., Kay J.M. eds. New York: Kluwer Academic Publishers, pp. 239-254.

Naik H.S., Sargunamani D., Ramatal S.S., 2011, Cost savings in cutting section of apparel industry, Indian Textile Journal, October 2011. (https://indiantextilejournal.com/articles/FAdetails.asp?id=4070)

Plossl G. W., 1988. Throughput time control, International Journal of Production Research, Vol. 26, No. 3, pp. 493-499.

Yadav R., Shastri A., Rathore M. 2012. Increasing productivity by reducing manufacturing lead time through value stream mapping, International Journal of Mechanical and Industrial Engineering, Vol.1, No.3, pp. 31-35.

Suresh N. C., Meredith J. R., 1994. Coping with the loss of pooling synergy in cellular manufacturing systems. Management Science. Vol. 40, No. 4, pp. 466-483.

Van der Heijden M. C., Alvarez E. M., Schutten J. M. J., 2013, Inventory reduction in spare part networks by selective throughput time reduction, International Journal of Production Economics, Vol. $143, \quad$ No. $2, \quad$ pp. $509-517$. https://doi.org/10.1016/j.ijpe.2012.03.020

\section{Biographical notes}

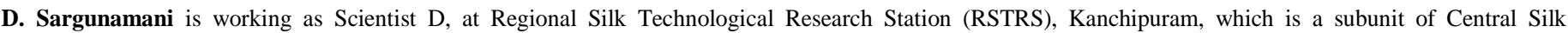

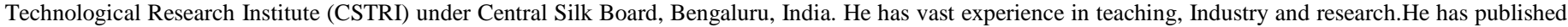

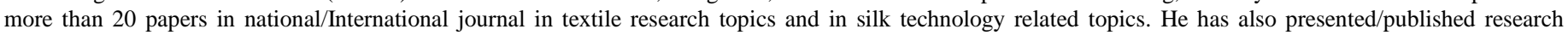
articles in national and international conferences.

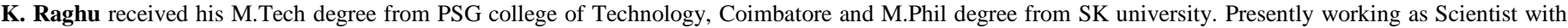
Central Silk Board having more 30 years experience. He has published and presented many papers in National/International journal and in Conferences.

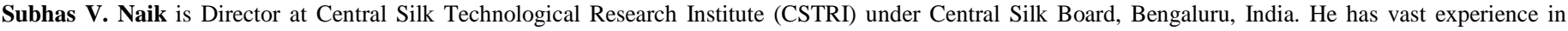

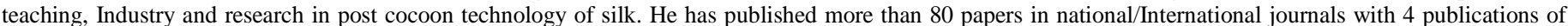
books in silk research topics. He has also presented more than 50 research articles in national and international conferences. 